\title{
Advantages and Constraints of Living Green Façade Systems
}

\author{
Francisca Amorim and Paulo Mendonça
}

\begin{abstract}
This paper comments on some technical aspects of living green façade systems, pointing out their advantages and constraints. This environmentally sustainable strategy for building construction and refurbishment is especially adequate for South oriented facades, more suitable for plant growing, contributing to reduce heat island effect, lower emissions and even a positive balance to buildings by absorbing $\mathrm{CO}_{2}$ and liberating oxygen due to photosynthesis process. Green facades can also reduce visual impact from buildings on landscape. The use and appreciation of native flora in these systems should be valued. In this paper some examples of green facades are presented and commented on their structural and functional specifications.
\end{abstract}

Index Terms-Green facades, sustainable construction systems, low emission buildings.

\section{INTRODUCTION}

With industrial revolution the transport of people and goods generalized. Industries started to be located near raw materials extraction sites, more for economic than environmental reasons, as this centralization of production increased the average distance of building products from the extraction to the work sites - with consequences on transport energy costs and pollutant emissions. In a pre-industrial revolution context, materials used in building construction were generally from local provenience. Apart from the increased transport costs, many building materials used in industrialized countries result nowadays from high energy demanding industrial processes, in detriment to natural and less transformed materials that characterized vernacular buildings [1].

The North of Portugal is characterized by sprawled territory occupancy, what is environmentally problematic due to infra-structures and transport increased costs. This reality has diverse causes: accented topography, division of soil due to multiple transmission of property, small delocalized industry, among others. The generalized access to individual transport means in the last decades accentuated these phenomena. More recently, the Portuguese economic context is changing drastically. Energy cost increasing, small

Manuscript received June 2, 2016; revised September 1, 2016. This work has financial support from the Project UID/AUR/04509/2013 by FCTMEC by national funding and, when applicable, FEDER co-financing under the new PT2020 partnership agreement.

F. Amorim is with School of Architecture, University of Minho,Azurém Campus, 4800-058 Guimarães, Portugal (e-mail: a61621@alunos.uminho.pt).

P. Mendonça is with Lab2PT Research Centre, School of Architecture, University of Minho, Azurém Campus, 4800-058 Guimarães, Portugal (e-mail: mendonca@arquitectura.uminho.pt). industries closing and unemployment are impelling the return to individual means of subsistence, such as poultry. But the urban sprawled occupancy frequently limits access to productive soils and sun exposure. The use of living plants on vertical facades and roofs can be one of the strategies that allow reducing the environmental impact of buildings and promote a better equilibrium between construction and nature.

\section{The Use of Living Plants ON BUILDINGS}

The inclusion of living green elements as a building construction material is not a new phenomenon, in spite that in many cases not completely taking advantage of their full potentialities.

The use of live vegetation in architecture was first associated with theso-called hanging gardens of Babylon, supposedly built by King Nebuchadnezzar II on 600 BC [2]. In accordance to several representations, this building presented several green roofs. In ancient Greece, corn and spices were planted on the roofs of the houses to honor Adonis. The Cult Garden emerged. In Roman gardens, pergolas with rambling roses and arbour trails rambling with grapevines already existed [3]. In Iceland, as well as in other Scandinavian countries vernacular houses uses a roof/wall green system for thermal insulation (Fig. 1).

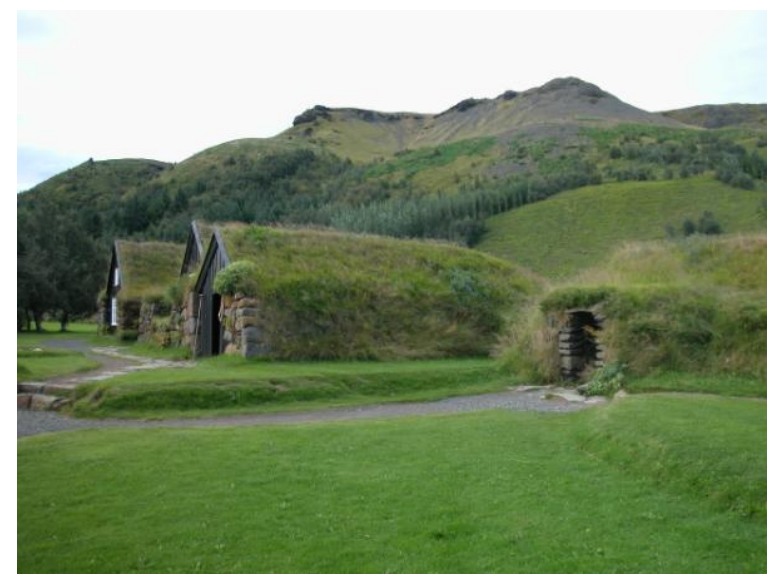

Fig. 1. Iceland vernacular houses.

In the late nineteenth century begin to appear the first ecological theories and concerns. The vertical garden is seen as a possible response to mitigate the problems associated with urbanization. The idea continued to grow resulting in the term "garden-city", where Ebenezer Howard equates the junction between the city and the countryside, in order to combat the growth of pollution in cities.

One of the most iconic $\mathrm{XX}^{\text {th }}$ century references is the Scheu 
House (1912-13) designed by the architect Adolf Loos, where vegetation is placed in one of the facades.

The first patent of a green wall - the "Vegetation-Bearing Architectonic Structure and System" was registered in 1938by Stanley Hart White, Professor at the University of Illinois Urbana-Champaign [4]. However, the contemporary development of the "vertical gardens" came from the work of the French botanist Patrick Blanc. What he proposes is the existence of a vertical panel substrate and an irrigation control system that, associated with the presence of nutrients, enables growing live plants without soil. Since 1988 he develops some examples with these fundamentals in many countries [5] Some of the best known are the museum Quai Branly in Paris, Vinet Square in Bordeaux, and Caixa Forum in Madrid (Fig. 2). This concept revolutionized the traditional idea of ground planted vegetation facade into vegetation applied directly to the wall. Nowadays, there are throughout the world many spaces where green facades have been incorporated.

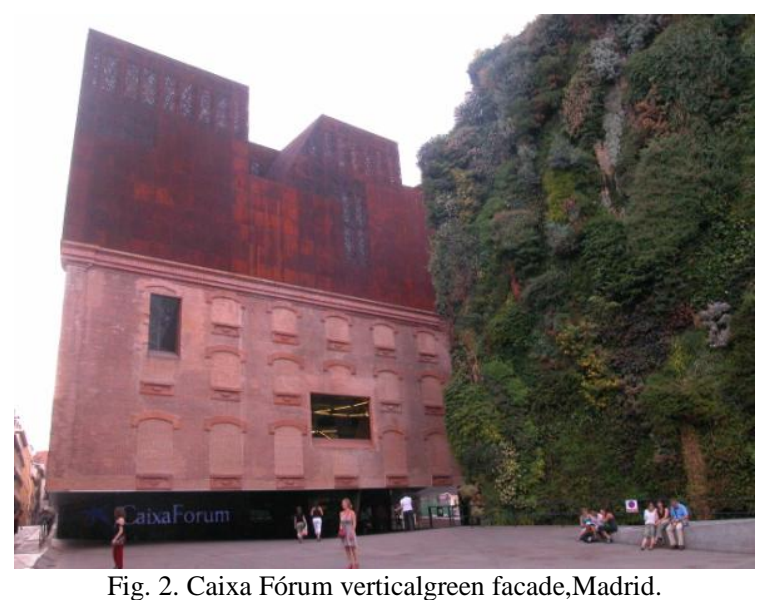

In order to take advantage of their potential, are beginning to emerge, more enthusiastically than ever, solutions in which the vegetation fills the entire façade of the buildings.

It is remarkable the growth of solutions that believe in the system of green facade as a promoter to improve the quality both indoors and outdoors. In fact, a facade that includes living vegetation can increase the energy efficiency of buildings, as it acts as a kind of protective shield against solar radiation and noise. It is capable of cooling in summer, providing shading and, moreover, can even act as heat insulation in winter.

Apart from being very efficient on passive cooling by shading and evapotranspiration, living green facades present very low embodied energy in comparison with other building cooling and heating systems. They allow rainwater retention decreasing the risk of flooding and contamination of rivers and streams. Green facades are still able to create dynamic changes on buildings' envelope, according to seasonal variations and plant ageing. It is desirable to make use of native plants and adequate agricultural techniques in accordance with its capability to be used in such structures [6]. This ensures the preservation of the cultural and economic values of a region, contributing to the local identity.

\section{GREEN FAÇADE CONSTRUCTIVE SYSTEMS}

The materials used in each technique are linked to the constructive solution chosen; however there are essential aspects to safeguard in order to assure it functions properly. The flexibility of the plant support structure is very important, since it should allow the healthy growth of the vegetable elements ensuring access to water and nutrients from the irrigation system. The structure should assure load-bearing capacity according to the plants life cycle and enable the absorption and retention of some water to avoid the need for constant irrigation [7].

As for specific techniques for green building facades, there are no established concepts. However some begin to show up as distinct, namely those shown on Fig. 3.

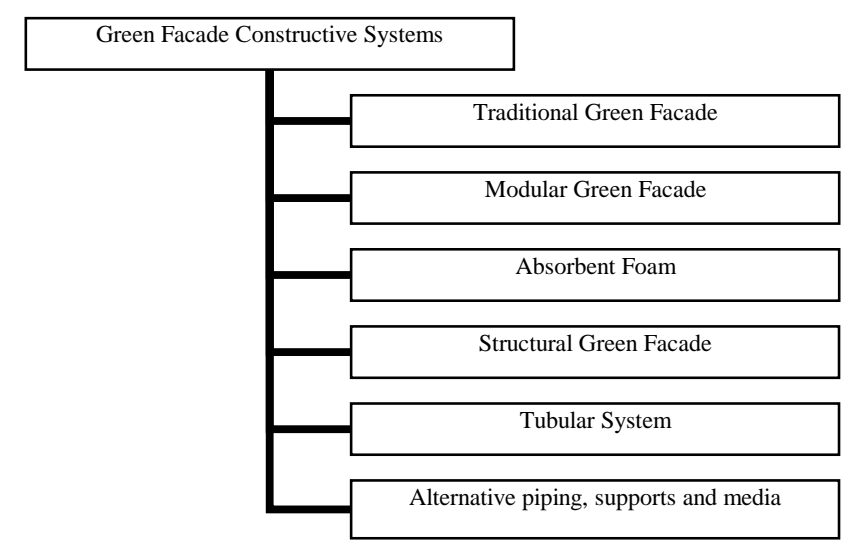

Fig. 3. Green facade constructive systems [7].

\section{A. Traditional Green Facade}

The so-called "traditional" system is the oldest and most economical green façade system and consists of planting in the soil the vegetable elements. Through natural mechanisms of adhesion or growing support structures (Fig. 4), the plants grow in front of the walls. It has the particularity to emerge after the construction of the building, and in many cases not intentionally in the first design.

However solutions begin to emerge where this mechanism is designed and planned. In this case, the live vegetation is used as constructive element in itself, with plants fixed in exact locations and manipulated as a construction element, coordinated with the building design.
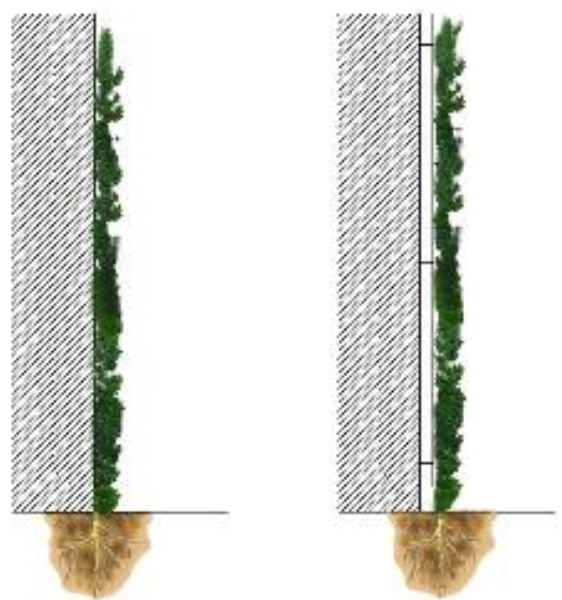

Fig. 4. Traditional system: natural fixing (left); growing support structure (right) [7].

An example of this technique is the Duncan Lewis project, 
West School Complex. In this project the facade is treated with vegetation having a key role in the climate and light control, linking the rhythm of the seasons to the internal spaces. The leaves of red plum leaning against the facade convey its reddish color to the interior (http://miesarch.com/work/884).

\section{B. Modular Panels Green Facade}

The main feature of this system lies in prefabricated modular panels (Fig. 5). There is a large variety of parts with different sizes, which allows performing complex shapes according to the desired solution. The modules are installed with the plants already placed on the sites where they will be after completion. Planting this system is simple: the substrate is compressed within the cells of the panels and species are planted, while the panel remains in a horizontal position. The irrigation system is made between the panels and water is drained through the whole facade, being collected at the bottom. The vertical garden at the Quai Branly Museum in Paris, by Patrick Blanc, is an example of this modular system with more than fifteen thousand species [5].
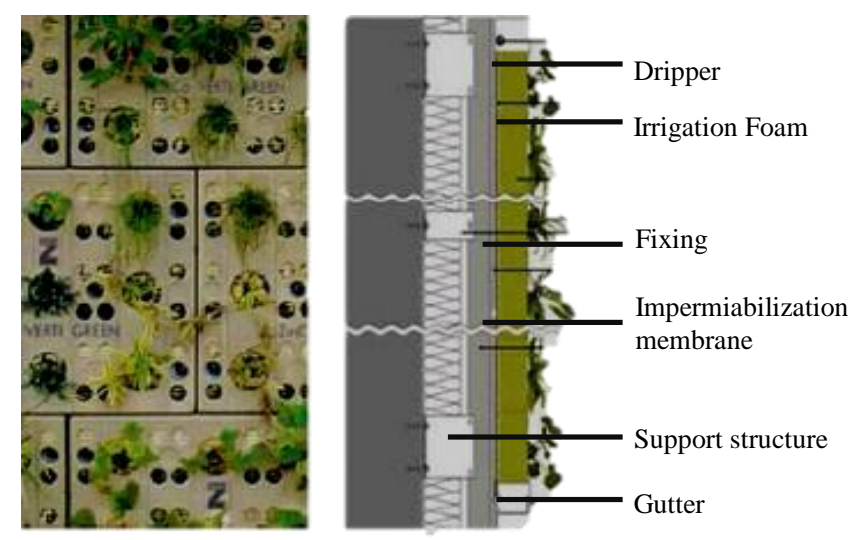

Fig. 5. Modular green façade (adapted from [3]).

\section{Absorbent Foam}

This system is similar to the modular system, with the distinction lying in the plant support. Two foams are juxtaposed and fixed through a staple system. At the exterior one are made cutouts that form "pockets" where plants are placed. The irrigation system is installed later. One example of this system is the Natura Towers by GJP Arquitectos Associados [5].

\section{Structural Green Facade}

Structural green facade means having vegetation from the beginning of the creative process, considering the positioning of the substrate, the irrigation and access for maintenance. There is a dependency relationship between the architectural solution and this system, since they complement each other. An example is the Banca Catalana in Barcelona, designed by Tous and Fargas architects and the botanical Jordi Aguilar. In this case, the vegetation is placed in steel recipients that surround the entire building. A corridor of $65 \mathrm{~cm}$ between the glass façade and the vegetation is formed [7].

\section{E. Tubular System}

This is a fully prefabricated system once it is installed. It can use fencing and posts which serve as structural support. It is surrounded by an absorbent foam layer which also supports the substrate where plants are contained. The substrate tube is attached to the structural support through connecting cables and, at its center, there is a core composed of an absorbent material pipe that allow water supply (Fig. 6). The excess flows into the base where accessories support the entire system and at the same time collect drained water [5].

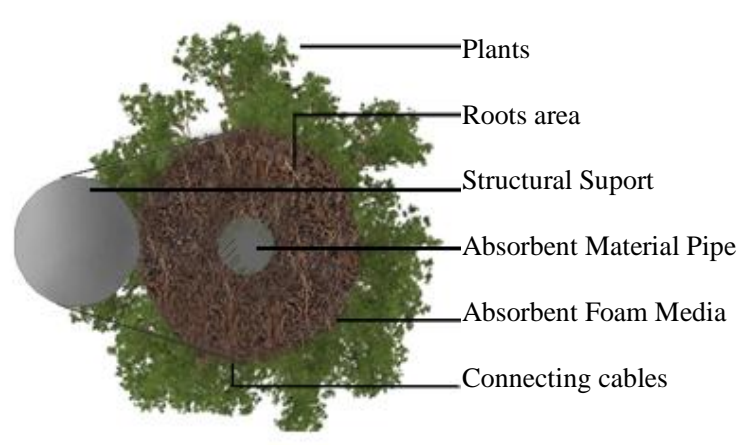

Fig. 6. Tubular system [7]

An example is the Urban Garden at O'Hare International Airport in Chicago. In the main hall of this airport grow fresh herbs that can be served in dishes chosen by travelers. This is an aeroponicculture with over a thousand plants of several distinct species, including: basil, chives, coriander, sage, thyme, oregano, among others. In addition to producing healthy and sustainable food, a positive impact is transmitted to the passers, conveying freshness and liveliness to the area. In this case, the seeds are germinated into small cubes, and transplanted to PVC circular towers only when the plants are mature [7].

\section{F. Alternative Piping, Supports and Media}

This system is wide scoped and varied and includes both the simplest structures as well as the most complex [7]. The simplest can be assembled by anyone without specific training when for example small recipients are used. The key is to ensure the operation of the whole system, since the design process of the structure, to the irrigation system. The vegetation is included from the design phase of the project.

The bottle reuse process created by architect Marcelo Rosenbaum can be integrated in this type of system [5].

Also the project "Between air" from the Spanish pavilion at the 2012Venice Biennale is of this type. It was conceived by the architects Jose Selgas and Lucia Cano, together with the biologist Josep Selga and the agronomist Juan Laureano. This project aimed to solve spatial and short income problems and therefore explores a renewed vision of nature linking it to technology. The installation consists of porous cylinders made of recycled plastic which are suspended. Through the openings light arrives to the root system. When the plant roots reach the air they dry, whereby a pruning allows the growth to be radial instead of linear. The method of bringing hydroponic plant nutrients eliminates the need for ground maintenance, increasing the yield of plants with lower costs. The various supports suspended from the ceiling are connected by steel plates, with a mechanism that allows movement in order to control the sunlight and the heat necessary for the life of the different species. 
In the Eco-Boulevard project in Madrid (Fig. 7), the whole structure becomes more complex and the use of vegetation appears in a distinct way. Here, a metallic structure supports small trees in the air (Air Tree) allowing cooling the site temperature and replacing the function of the ground planted trees, while they do not acquire a significant size. This not only provides a good environment within these structures, but also creates a microclimate. This strategy can certainly be a response to some of the environmental problems of large urban centers where green areas are almost non-existent and where no ground is available for planting.

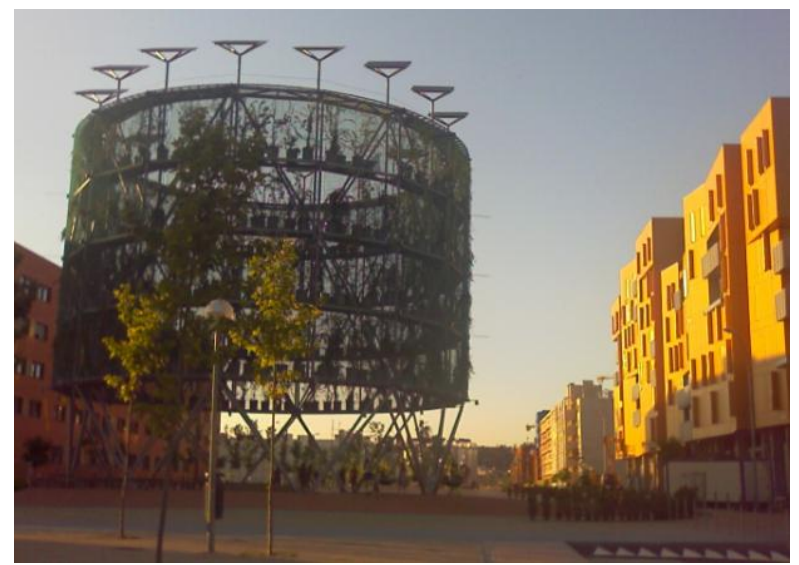

Fig. 7. Eco-boulevard of Vallecas, Madrid.

\section{IRRIGATION SYSTEMS}

In green walls, a water irrigation system is essential for the plants survival, because through it also the necessary nutrients are conducted.

When it comes to the traditional system where the root is on the ground next to the facade, irrigation can be manual at the foot of the plant as in conventional gardens, or by an automatic drip system.

When the vertical gardens' systems are more complex, there are other irrigation methods more suitable for each case.

\section{A. Irrigation System for Modular Panels}

For modular panels, the installation and operation of the system are thought prior to arrival on site. Usually the irrigation system is by drip, with water released at the top of the wall. In this case, modules can be separated by small orifices that distribute to other compartments of the wall plants support and the excess collected or released on the bottom (Fig. 8).

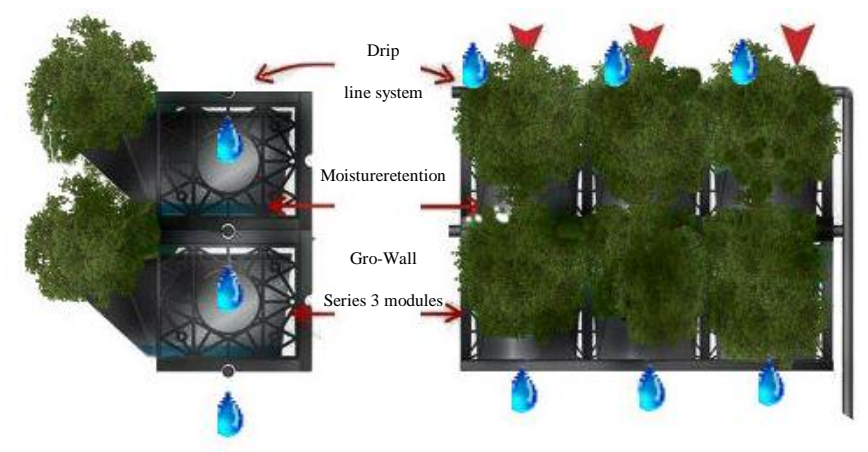

Fig. 8. Irrigation system for Modular Panels (adapted from http://www.enter-shop.com.au).

\section{B. In Situ Irrigation System}

This is a more complex system where the network pipes are not in sight, being involved by foams or other filter layers.

The substrate is evenly wet and must remain wet until the next sequence of water irrigation.

\section{Vaporization System}

This is a system in which rain water is harnessed, treated and distributed to plants through vaporization. The tubes are at the outside and make the supply of water and nutrients.

\section{D. “Ecoesgoto” System}

This system was created by a Brazilian company in order to reuse water from sanitary discharges and food scraps for use in irrigation of gardens, green roofs and facades with nutrient supply. At the bottom this system treats all organic waste from the building (Fig. 9).

The treatment of the organic waste is integrated in the system itself using a biological filter and then distributed to the green roofs and facades. No chemicals are used, and maintenance is reduced. The system is also used to capturera in water and as an insulation barrier, generating savings in HVAC systems.

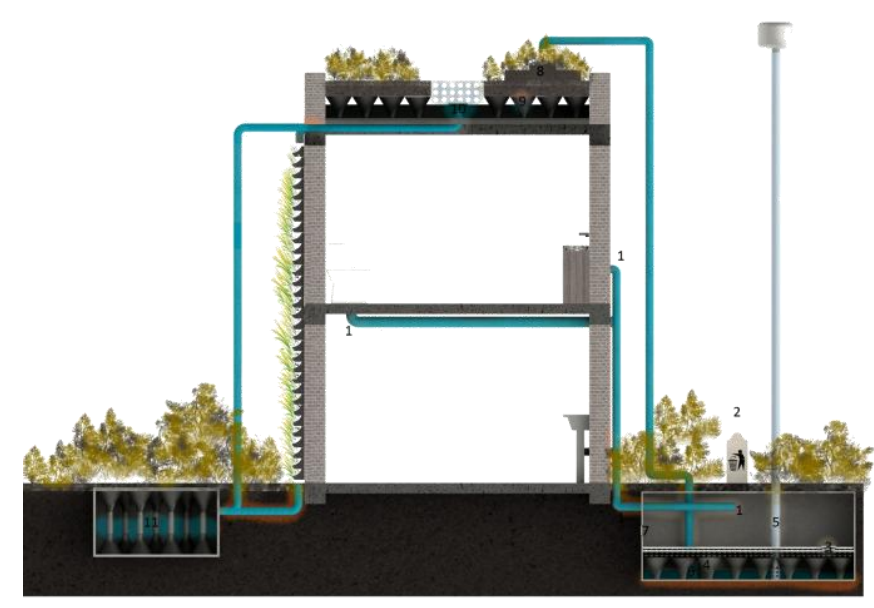

Fig. 9. "Ecoesgoto" system (adapted from www.dca.arq.br). Legend: 1 sewer; 2 organic waste; 3 aerobic filter; 4 raised floor "Ecodreno"; 5 exhaustion; 6 TreatedWaterPump Reservoir 7 worms filter; 8 rhizoremediation; 9 laminar system (optional); 10 WaterOutlet; 11 permeable reservoir.

This system is a sustainable alternative to decentralize wastewater treatment. In Brazil and other countries in Latin America, Africa and Asia, the technology aims to solve sanitation problems, still very present.

This idea came from the need to promote a sustainable solution for the irrigation of green roofs and walls, which consumes a lot of water and nutrients that can be scarce and expensive in many contexts.

\section{COMPARATIVE ANALYSIS}

Despite the advantages already known that vegetation brings and its characteristics for a good interior and exterior environment conditionings, the green façade systems are still subject to criticisms concerning their good operability.

One is linked to the issue of the system's thickness that, in architecture, is very relevant, since it interferes with available 
area issues and space organization, often quite restricted. The fact that it requires more specific materials, including substrate foams and irrigation systems, not solved in most conventional systems, means that the complexity of these solutions is high, what can often be deterrent to their adoption. However, the fact that the thickness of the outer wall is greater creates an increased barrier between the outer and inner limits, solving problems related to thermal and acoustic protection [7].

When analyzing the different green façade constructive systems specifications (Table I) we have the perception that many questions can be raised when there is a need to decide between different solutions.

In these systems, irrigation could possibly be manual. However, if this happens who could guarantee that the vegetable elements would be effective over the lifetime of the building? How would assure indoor environment quality if further maintenance of the plants does not exist? This wall would cease to perform their functions as barrier and the building performance would be at risk? [7]

The traditional and the modular systems present the advantage that structural elements may be removed or replaced, creating independence between the plants and the building. This facilitates the change in case of anomalies in specific locations, or even the complete substitution of the system.

TABLE I: GREEN FAÇADE CONSTRUCTIVE SySTEMS SPECIFICATIONS [7]

\begin{tabular}{|c|c|c|c|c|}
\hline $\begin{array}{l}\text { Green Facade } \\
\text { System (GFS) }\end{array}$ & $\begin{array}{c}\text { Plants } \\
\text { (preferably) } \\
\text { Selected }\end{array}$ & $\begin{array}{c}\text { Maximum } \\
\text { high of the } \\
\text { wall }\end{array}$ & $\begin{array}{c}\text { Irrigation } \\
\text { System }\end{array}$ & Maintenance \\
\hline $\begin{array}{c}\text { Traditional } \\
\text { Eg: West School } \\
\text { Complex }\end{array}$ & Rambling & $30 \mathrm{~m}$ & $\begin{array}{l}\text { Natural or } \\
\text { automatic }\end{array}$ & Pruning \\
\hline $\begin{array}{l}\text { Modular } \\
\text { Eg: Quai } \\
\text { Brandley } \\
\text { Museum }\end{array}$ & Bushes & Unlimited & Drip & $\begin{array}{c}\text { Pruning or } \\
\text { substitution }\end{array}$ \\
\hline $\begin{array}{l}\text { Absorbent } \\
\text { Foams } \\
\text { Eg: Natura } \\
\text { Towers }\end{array}$ & Bushes & Unlimited & Drip & $\begin{array}{l}\text { Pruning or } \\
\text { substitution }\end{array}$ \\
\hline $\begin{array}{c}\text { Structural } \\
\text { Eg: } \\
\text { BancaCatalana }\end{array}$ & $\begin{array}{l}\text { Bushes/ } \\
\text { rambling }\end{array}$ & Unlimited & $\begin{array}{c}\text { Natural / } \\
\text { Drip }\end{array}$ & Pruning \\
\hline \begin{tabular}{|c|} 
Tubular \\
Eg: O'Hare \\
Internacional \\
Airport \\
\end{tabular} & Rambling & Unlimited & Drip & $\begin{array}{l}\text { Pruning or } \\
\text { substitution }\end{array}$ \\
\hline $\begin{array}{l}\text { Alternative } \\
\text { piping, supports } \\
\text { and media } \\
\text { Eg: Eco- } \\
\text { Boulevard } \\
\end{array}$ & Bushes & Unlimited & $\begin{array}{c}\text { Drip / } \\
\text { Natural }\end{array}$ & $\begin{array}{l}\text { Pruning or } \\
\text { substitution }\end{array}$ \\
\hline
\end{tabular}

The inconvenient of these systems, and especially with the modular, is the need for an irrigation system which must function independently from the modules and near the building wall. It presents a risk factor for interstitial condensation and consequently bringing moisture transfer into the interior when poorly waterproofed.

Another concern with green walls is related with the growth of roots and plants that can be part of the system or even weeds. The fact of receiving water and nutrients can become detrimental when not controlled, leading to an increase in volume and consequently greater weight to the structure. This brings effect not only related to the thermal efficiency of the building, but also with its structure and safety [7].

The risk of fire is also one of the issues discussed and related to different green facade systems. There is no guarantee that the species cannot dry when the treatment and conservation are not well addressed or the irrigation system fails. Furthermore, as they are located in exterior solar exposed walls, they are more subject to temperature changes and adverse conditions. Green facades cannot always assure the same image because, in the case of living species, their behavior cannot be controlled in its entirety, with changes in color, size and even the foliage. Another problem related to green walls is the waste that some species creates.

Many of the green wall systems are innovative solutions, requiring skilled labor and consequently more costs to the building construction. Maintenance costs should also be considered to assure that the system will function as intended.

\section{CONCLUSIONS}

Although this paper doesn't specify all the detailed characteristics of each construction and irrigation system for green walls, it points out the general properties that characterizes and that can be used to choose between them. Thus, there are solutions that are closer to the architecture itself, in the sense that they are conceived in the first design stages (e.g. the structural system) and others that can be installed later, more or less intuitively (e.g. traditional system).

\section{REFERENCES}

[1] P. Mendonca, "Living under a second skin - Strategies for the environmental impact reduction of solar passive constructions in temperate climates," $\mathrm{PhD}$ thesis, University of Minho, 2005.

[2] C. Uffelen, "Façadegreenery - Contemporary landscaping," MSc Thesis, Lisbon, 2012.

[3] G. Broadbent and C. A. Brebia, Eco-architecture II - Harmonization between Architecture and Nature, WIT Press, Southampton, Boston, 2008.

[4] R. L.Hindle, "A vertical garden: origins of the vegetation-bearing architectonic structure and system (1938)," Studies in the History of Gardens \& Designed Landscapes: An International Quarterly, vol. 32, no. 2, pp. 99-110, 2012.

[5] J. Silva "Green roofs and facades," MSc thesis in Militar Engineering, Lisbon, 2012.

[6] F. M. G. Delgado et al.,"Vegetação autóctone aplicada a painéis de cobertura e fachadas verdes de edifícios urbanos- projeto geogreen," Jornadas Ibéricas de Horticultura, 5, Faro: Actas Portuguesas de Horticultura, vol. 19, pp. 328-340, 2011.

[7] F. Amorim, "The vegetation on the outer envelope of buildings: Impacts, constraints and eco-efficient intervention strategies," MSc thesis, University of Minho, 2015.

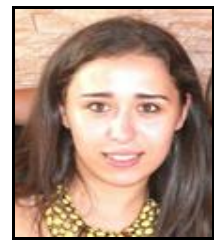

Francisca Amorim was born in Ponte de Lima in 13th March 1992. She concluded the master degree in architecture by the University of Minho, Portugal (2015) with the thesis "The vegetation on the outer envelope of buildings: Impacts, constraints and eco-efficient intervention strategies". It seeks to develop a modular housing structure with vegetable materials, easy to build, which can be assembled in different ways and capable of being expanded and at the same time allowing the building to spend the minimum energy possible both in construction as well as on the use phases. The main research subjects includes the use of vegetable materials in buildings, sustainable development, new materials and technologies. 
Paulo Mendonça was born in Porto in 10th June 1969 $\mathrm{He}$ got the $\mathrm{PhD}$ in civil engineering by the University of Minho, with the thesis: "Living under a second skin", (2005). With a PhD fellowship from FCT (Portuguese Foundation for Science and Technology) he got the "Advanced Studies Diploma" in Barcelona on the Technical Superior School of Architecture (ETSAB). He was a JNICT (former FCT) fellowship student in the Textile Engineer Department of the University of Minho, where he obtained the Master Degree defending a thesis about "Intelligent Textiles in Architecture" (1997). He Graduated in Architecture by the University of Porto, Portugal (1994). He was Erasmus granted student in ETSAB, Barcelona (1993-1994).

$\mathrm{He}$ is associate professor in the Architecture School of the University of Minho, Portugal (EAUM) and coordinator of the research group DeTech of the Lab2PT Centre. He was President of EAUM (2011-2012) and vice-president (2010-2011). Architectural Graduate and Integrated Master Studies Director (2005-2009). Author of more than one hundred publications including: books (7), papers on journals (29), book chapters (7), papers in proceedings books with peer review (84). His research is in six concluded research projects. He is author of three patents of invention. Since 1995, during his MSc thesis he started in the specialization field of "Lightweigh Constructions", progressively devoting his research interests to the area of Building Physics and Sustainability. The main research subjects includes lightweight and mixed weight buildings, low cost housing, local and global economic asymmetries, low-tech strategies, energy costs and sustainable development, new materials and technologies, recycling and reusing potentialities. 